\title{
СОЦІОЛОГІя
}

\author{
УДК 37.035:37.03
}

DOI https://doi.org/10.32837/apfs.v0i28.945

\author{
I. В. Варнавська \\ ORCID ID: https://orcid.org/0000-0002-3061-0665 \\ кандидат педагогічних наук, доцент, \\ доцент кафедри професійної освіти \\ Херсонського державного аграрно-економічного університету
}

\section{СУЧАСНІ ПОГЛЯДИ НА ПРОБЛЕМИ МОРАЛЬНОСТІ ЯК ВАЖЛИВОГО АСПЕКТУ ФОРМУВАННЯ ОСОБИСТОСТІ МОЛОДІ УКРАЇНИ}

Сьогодні стан моральної освіти в країні є незадовільним. Зруйновано систему освіти, яка не тільки задавала ідеологічні орієнтації, а й надавала духовні, моральні та естетичні знання. Унаслідок цього розвиваються вседозволеність і цинізм щодо моральних цінностей народу, вироблених ним протягом багатовікового існування, і до патріотизму також. Об'єктивною реальністю стало наростання негативних тенденцій у дитячому i молодіжному середовищі.

Все це свідчить про необхідність посилення ідейно-морального виховання дітей і молоді, а отже, і поліпшення підготовки педагогічних кадрів.

Сучасний педагог повинен бути здатний до багатоваріантності педагогічних дій, прогнозування важливих виховних результатів, проєктування розвитку особистості, а також він має уявляти, якого громадянина і патріота Батьківщини йому необхідно виховати. Успішне вирішення завдань виховання, істотне поліпшення всього педагогічного процесу, розвиток пізнавальної, трудової активності дітей і молоді безпосередньо пов'язані 3 удосконаленням підготовки педагогів, їх професійно-педагогічної майстерності, ерудиції та культури (як загальної, так і професійної).

Педагог, який сьогодні необхідний закладу, повинен бути широко і всебічно розвиненою духовною особистістю, здатною приймати самостійні моральні рішення, здійснювати вчинки й дії. Він має усталені моральні принципи, володіє широким світоглядом і знаннями в моральній сфеpi. Від того, як розгляне ці питання сам педагог, залежить його здатність виховати дитину. Тому виховання інших треба починати із самовиховання, 3 вироблення своєї системи цінностей, адже засвоєння підготовлених знань без опанування діяльністю, в результаті якої ці знання отримані, формує догматичне, автократичне та як висновок - антидіалектичне мислення. При цьому важливе значення має відповідна підготовка май- бутніх фахівців економічного напряму в процесі навчання у закладі вищої освіти.

Традиційна система, яка існує у підготовці студентів до морального виховання, виходить 3 того, що у змісті виховного процесу $є$ «якась усереднена і спрощена мораль» [5, с. 42-44]. Це припущення грунтується на предметних знаннях (знаннях-описах), які описують, пояснюють світ таким, яким він $\epsilon$ на сучасному рівні пізнання. У реальності ж процес виховання в суспільстві відбувається в зіткненнях, протидіях різних ідейних і моральних позицій. Тому для того, щоб вирішувати моральні проблеми, які найчастіше виникають, здобувачам необхідні знання-розпорядження (методи пізнання). Вони наказують суб'єкту, що і як він повинен робити, щоб опанувати предметні знання (знання-описи). Ось цих знань-передписань насамперед і недостатньо навчаються здобувачі, щоб правильно використати свої предметні, в цьому разі моральні, знання. Чим же пояснюється, що учні переважно отримують знання i не навчаються (або навчаються недостатньо, неповно) вдало використовувати розумові здібності. Адже для того, щоб здійснити моральний вплив, необхідно для початку провести розумову дію.

У закладах освіти здебільшого не заохочується самостійність, своєрідність мислення. Якщо невідомі, наприклад, шаблонні оцінки образів літературних героїв, обов'язкові для учнів, хоча однаково шановані літературні критики нерідко стояли на діаметрально протилежних позиціях. До сьогодні не застосовуються у примітивному «шкільному літературознавстві» шаблони - одна 3 найважливіших причин поширення шпаргалок - «зразкових» текстів творів. Хоча 3 логіки викладання педагог повинен допомогти учневі самостійно висловити свою думку, моральне бачення проблеми.

Одне 3 важливих завдань сучасного закладу освіти - навчити школярів вчитися, зробити їх здатними знаходити та засвоювати нові для них 
знання. Навіть більше, ставити нові питання, а не тільки знаходити відповіді на поставлені запитання. Чи відбувається реалізація цього аспекту в сучасному закладі освіти? Відомо, що студенти-першокурсники часто із труднощами адаптуються до свого нового соціального стану, а іноді змушені припинити навчатися у ЗВО. Найважливішим чином тому, що вони не вміють вчитися, школа не навчила їх цього. Причиною найчастіше $є$ незнання навчальних розумових операцій, із яких складається рішення певних завдань, а також недостатне розуміння того, що для ефективного навчання треба ці операції виявити і спеціально навчати їх.

Зазвичай випускник закладів загальної середньої освіти не вміє конспектувати книги та статті, добирати потрібну літературу, користуватися довідниками і каталогами бібліотек, складати бібліографію, тобто не вміє здійснювати велику кількість справ, елементарних для освіченої людини сучасного світу. Зрозуміло, здобувачі тією чи іншою мірою здобудуть ці вміння і навички. Але ж вищу освіту отримає один із чотирьох випускників школи, а перераховані та багато інших навички потрібні практично кожній сучасній людині. Зокрема, такі навички - це запорука ефективності самоосвіти для тих, хто після школи починає працювати.

$\mathrm{y}$ наш час наявна система підготовки здобувачів орієнтована насамперед на озброєння їх лише предметною стороною наукового знання, що $\mathrm{e}$ неповним, одностороннім підходом. Повноцінне опанування наукових знань включає засвоєння принципів і методів отримання цього знання, а також практичного його використання. Без цього неможлива активна і компетентна участь здобувачів у вирішенні проблем морального виховання, оскільки, опановуючи наукові знання в єдності їх предметної і операційної сторони, здобувачі засвоюють і певний підхід до процесу і результату навчально-виховної діяльності. Такий підхід у разі цілеспрямованого його формування стає надбанням здобувача, стилем його мислення, що у висновку стає для нього звичною дією.

Суспільство сьогодні як ніколи потребує педагога, якому притаманні активна громадянська позиція, динамічність, уміння швидко реагувати на зміни в складних ситуаціях, а також робити правильний вибір у нестандартних моральних ситуаціях, самостійність у прийнятті рішень, почуття відповідальності за виконувану роботу. Вся повсякденна практична діяльність педагога вимагає від нього напруженого, самостійного, відповідального мислення, необхідного для вирішення різних і часом дуже складних моральних проблем і питань. Так було завжди, але особливо це характерно для сучасного етапу розвитку педагогічної практики.
За час навчання у закладі вищої освіти здобувачі повинні засвоїти, що психологічні закономірності мислення як процесу (пошуку і відкриття нового) цілком і повністю поширюються передусім на розумову діяльність педагога. У повсякденній практичній діяльності будь-якого педагога дуже часто несподівано виникають або цілеспрямовано створюються нові життєві ситуації морального плану - під час заняття, на перерві, під час виховного заходу. Необхідно швидко, правильно і переконливо, з моральної позиції оцінювати той чи той вчинок учня, вчинений з не завжди зрозумілих мотивів; з'ясовувати причини несподіваного конфлікту між учнями тощо, тобто здійснювати розумові дії. Можуть бути два джерела знань про діï, які потрібно здійснити для вирішення того чи іншого завдання: інформація ззовні (з розповіді, як потрібно діяти, вказівок, інструкцій, показу, а також спостереження, як діють інші) і усвідомлення своїх дій. Зрозуміло, що найважливіше у навчанні - навчити здобувачів володіти діями, але знання і усвідомлення їх - найважливіший шлях до досягнення мети.

у більшості соціологічних досліджень, які проводились в Україні в період сучасної соціальної трансформації, динаміка ціннісних орієнтацій молоді трактується як перехід від традиційних цінностей до постмодерних. У дослідженні під керівництвом С. Лапіної висунута теза про близькість культури постмодерну і сучасної молодіжної культури, яка розглядається на тлі «традиційних» зразків моральності попередніх поколінь. Аналогічно у своїй монографії Л. Титаренко фактично ототожнюе традиційні, вкорінені в народній культурі, християнські та загальнолюдські цінності, протиставляючи їх цінностям посттрадиційним [8, с. 147]. Таким чином, у цих прикладних соціологічних дослідженнях «традиційними» є усталені у цьому суспільстві феномени в порівнянні із поточними змінами.

Тим часом у соціальній філософії концепт «традиційне суспільство» виник як антитеза поняттю індустріального суспільства епохи «модернити». У цьому разі традиційними моральними цінностями є специфічні переваги аграрної цивілізації, до числа яких належать патріархальні взаємини між старшими та молодшими, чоловіками й жінками; уявлення про землю як головної життєвої цінності та засновані на цій прихильності працьовитість і патріотизм; органічний колективізм і що випливають звідси обов'язки особистості щодо товариства.

Мораль втілює застарілі цінності: свободу, індивідуалізм, професіоналізм і громадянський патріотизм, автономію особистості і ї̈ внутрішню саморегуляцію, раціоналізм і універсалізм. Для західних суспільств цей набір став по-своєму традиційним. 
Для відновлення соціальних зв'язків і моральних відносин, моральної свідомості суспільству необхідно звернутися до історичних підстав, традиційних для всіх верств населення, до так званих «простих норм моральності». Адже люди, які звикли жити «за старим укладом», розлучилися 3 ідеологічними ілюзіями, але не з корисними моральними звичками: старанно працювати, піклуватися про сім'ю, підтримувати громадський порядок. Історично національні цінності українців, християнські і радянські моральні орієнтації виявилися в якомусь сенсі єдині і утворили ту «традиційну мораль» нашого суспільства, яку і фіксують соціологічні дослідження.

Іншою світоглядною основою стабілізації морального життя суспільства виступив, як не дивно, постмодерн. Постмодерний соціум постає не як сфера виконання обов'язків, а як світ споживання, в якому виникає індиферентне до моралі соціальний і духовний простір без напруженого протистояння сущого i належного. Функціонування постмодерної моральності передбачає ситуативність і поліваріантність моральних рішень, релятивізм з етичного пороку перетворюється на найбільше надбання моральної людини, яка здатна прийняти людей, які оточують, такими, якими вони є, вміє вирішувати різноманітні поточні ситуації.

У цьому аспекті можна провести паралель між молодіжною культурою і культурою постмодерну. Обидві відрізняє невизначеність оцінок і плюралізм уявлень, що перетворився на принципову життєву позицію. Як стверджувала Т.I. Яковук, суперечливі переконання в умовах відсутності моральних міркувань мирно співіснують, не стикаючись один з одним, не ведуть до пізнавального конфлікту. Навіть «ті 3 наших співрозмовників, хто відносив себе до мораліста, не змогли точно сформулювати моральні принципи, які особисто для них служать життєво важливими орієнтирами» $[10$, с. 101]. Тому соціологічні дані про ціннісні орієнтації сучасної молоді часто суперечать один одному, навіть у межах одного дослідження відбуваються суперечливі висновки.

Все це говорить про нестійкість, мозаїчність та хаотичність моральної свідомості сучасної людини. Однак реакція молоді на плюралізм моральних цінностей не перебуває у відмові від них, «бачення багатовимірності явищ, як абсолютно природний імпульс, не породжує розгубленість, невпевненість, світоглядного дискомфорту. Для молодих це багатоаспектний світ. При цьому формулювання його оцінок є не результатом світоглядного коливання, а результатом певного розуміння дійсності, яка сприймається цілком природно» [10, с. 101]. Інакше кажучи, постмодерний світогляд - це не проста байдужість до традиційної моральної спадщини, а й пошук нової системи моральних орієнтацій, однією з яких стала толерантність.

Глобалізація і мультикультуралізм викликав породження потреби співіснування як окремих людей, так і систем моральності з багатьма іншими, хоча деякі автори вважають толерантність не новою, а традиційною якістю українського національного менталітету, яка історично зумовлена прикордонним положеннями країни між Заходом і Сходом, католицизмом і православ'ям. У будь-якому випадку ця цінність відіграє все більш значну роль у житті наших молодих сучасників. У дослідженні T.I. Яковук 71,4\% опитаних погодилися із висловом «моє середовище витримує «іншим». Воно розуміє, що кожен живе і мислить по-своєму. Ми вважаємо це природним» [10, с. 101]. Однак із терміном «толерантність» молоді люди знайомі недостатньо i найчастіше розуміють його в аспекті міжособистісного спілкування як терпимість до конкретних недоліків оточуючих. Толерантність - це здатність адаптуватися до існування у соціумі різних систем моральних уявлень.

Одним із проявів толерантності може вважатися зміна норм статевої моралі. До того ж сім' я у сучасної молоді незмінно входить до п'ятірки провідних життєвих цінностей, дошлюбні статеві зв'язки більше не засуджуються. Згідно 3 дослідженням B.I. Каравкіна до цивільного шлюбу позитивно ставляться 54,5\% молодих людей, 25,5\% вважають його прийнятним, але не для себе, і тільки $11 \%$ вважали його неприпустимим. При цьому відповіді на це питання юнаків і дівчат практично не відрізняються. Нетрадиційну сексуальну орієнтацію спокійно сприймає $48 \%$ дівчат і 13,3\% юнаків. Більшість опитаних не засуджують короткочасні i безладні статеві зв'язки [3, с. 70-72]. Це свідчить про руйнування в молодіжному середовищі традиційного культу дошлюбної невинності і подружньої вірності, про спокійне ставлення до нетрадиційних форм сексуального досвіду. Звертає на себе увагу позиція «схвалюю, але не для себе», уведена В.I. Каравкіним за кількома питаннями. Її прихильники (близько третини опитаних) виявляють толерантність в чистому вигляді: приймають якусь практику не тому, що нею займаються, а розуміють, що вона може здаватися привабливою для інших. Не менш показово, що 98,5\% респондентів в дослідженні T.I. Яковук погодилися із судженням «у мене $\epsilon$ власне ставлення до сексу, і воно особисто для мене є важливим і обов' язковим. Але одночасно я вважаю, якщо хто-небудь до цього ставиться інакше, ніж я, то будь ласка. Секс - це особиста справа кожної людини». Така позиція повністю відповідає установкам постмодерної культури, яка не тільки відмовилася від статевої моралі 
минулого, а й породила нові норми в цій галузі, однією з яких є терпимість до сексуальних вподобань іншого.

Така постмодерна установка, як захист особистого простору, невтручання в життєві практики індивіда, якщо вони не зачіпають інтереси інших, у повному обсязі підтримується сучасною молоддю. Із думкою «найбільше мене вражає вторгнення в особистий простір іншої людини, розпитування, непотрібні поради; нехай кожен живе і думає, як хоче, це його особиста справа» погодилися $71,4 \%$ респондентів, і тільки $14,3 \%$ виявилися проти. Серед вчинків, беззастережно засуджених двома третинами опитаних, виявилися ті, які $€$ посяганням на приватне життя особи: мати читає листи, адресовані доньці; фоторепортери полюють за світлинами знаменитостей; дівчина обговорює з друзями особисту проблему своєї подруги, якою та $з$ нею поділилася.

Навіть коли якісь вчинки іншої людини сучасний індивід вважає негативними, він змириться із ними, адже значимість класичних «добра» $\mathrm{i}$ «зла» відступає перед прагненням до мирного співіснування із оточуючими. «Терпимість цього покоління молоді до “поганих" вчинків є в певному сенсі результатом ї̈ афіляційно-альтруїстичних переконань з акцентом на поглиблення внутрішнього духовного життя» $[10$, с. 101]. Потреба у доброзичливих відносинах з іншими людьми виявляється важливішою, ніж відповідність їх поведінки якимось абстрактним нормам і принципам. Так, у постмодерному соціумі виникає норма, неможлива в традиційній моральності: зберігати будь-яке, а не тільки корисне, високодуховне, або загальнолюдський значний вияв індивідуальності.

Дослідження ціннісних орієнтацій молоді України показують, що протягом останніх 15 років відбулася не тільки повна переорієнтація суспільної свідомості з принципу колективізму на принцип індивідуалізму, але і змістовна еволюція індивідуалізму. У нашому суспільстві існує низка типів індивідуалізму різного походження. Індивідуалізм може бути звичайним егоїзмом i виявлятися у свавіллі та аморальності. Передумови класичного індивідуалізму, який передбачає в кожній особистості здатність сформувати й реалізувати моральну програму як складник власної волі і розуму, з'явилися в нашій країні з розвитком ринкової економіки. Нарешті, системна трансформація нашого суспільства наблизила нас до глобальної постіндустріальної цивілізації, в якій індивідуалізм виражається не стільки в індивідуальній діяльності, скільки в індивідуальності споживання, а також в індивідуальності способу життя. «Це покоління, що не включає в межі свого соціального досвіду макросоціальні структури..., обмежується вільно створюваними індивідуальними життєвими стратегіями» [10, с. 101].
Індивідуаліст такого типу не протиставляє себе суспільству, бо основні сфери його самовираження існують не всупереч, а завдяки налагодженим соціальним зв'язкам.

Панівне трактування індивідуалізму в середовищі сучасної молоді передбачає усвідомлення своєї індивідуальності й неповторності. Для молодих людей індивідуалізм - це не стільки принцип поведінки в соціумі, скільки спосіб набуття себе, протистояння стереотипам масової свідомості і усвідомлення того, що найважливіша цінність у світі - особистість. Можна погодитися з висновком T.I. Яковук, що «йдеться про можливість прояву індивідуального початку, яке зовсім не обов'язково, на думку молоді, має протистояти загальним» [10, с. 101]. В 1̈ї дослідженні чітко простежуються ознаки нового типу індивідуалізму, який формувався не в «боротьбі за свободу», не в протистоянні суспільству, а в безмежному самовираженні всередині наявного соціального порядку.

Існування типу індивідуаліста-конформіста підтверджується і в дослідженні, проведеному під керівництвом С.В. Лапіної. Типовим представником молодіжного середовища виступає «індивідуаліст, досить пасивно сприймає вплив навколишнього середовища, але як включений в нього, схильний до конформізму і орієнтацій, характерних для суспільства. "Декларований індивідуалізм в поєднанні зі схильністю до прийняття тотальних соціокультурних цілісності, в яких розчиняється індивідуальність, на практиці може обернутися своєю протилежністю». Крім того, було виявлено, що властиве культурі «модерніті» уявлення про індивідуалістичне як активного діяча, а колективіста як людину, що пасивно сприймає традиційно сформовані способи життя, не відповідає справжньому стану речей. Для сучасного суспільства характерний «колективіст, активність або пасивність якого знаходиться в залежності від вектора впливу на нього соціокультурного оточення». Гіпотеза про наявність у студентському середовищі колективістів та індивідуалістів як протилежних за моральною орієнтацією групи на сучасному етапі не отримала підтвердження. Навіть явна перевага будь-якого принципу не означає прийняття супутніх «компліментарних» цінностей і тим більше його поведінкову реалізацію [5, с. 27-36; 6, с. 218].

Ознакою постмодернізації моралі виступає заміна колективізму комунітаризмом, прагненням утворювати спільноти, засновані на приватних інтересах і особистих уподобаннях, об'єднані особливим способом життя. Тому індивід епохи постмодерну не є одиноким та асоціальним суб'єктом. Про відсутність у молодих людей ізоляціоністських настроїв свідчить високий статус дружби і любові в ієрархії життєвих цінностей. У дослідженні Л.І. Шумської [9, с. 176] здобува- 
чі всіх курсів поставили дружбу на перше місце, навіть вище, ніж здоров'я. В опитуванні О.В. Русецького дружба і любов очолили список з 16 ціннісних орієнтацій студентів [7, с. 62]. Загалом у суспільній свідомості нашого суспільства відбулася переорієнтація із громадських проблем на особисті інтереси, звуження соціального горизонту до кордонів найближчого оточення. Моральна тематика сучасності перемістилася зі сфери відносин «особистість - суспільство» в іншу - «особистість - особистість». ЖКиттєвий простір і сфера самовираження особистості ототожнюються 3 мікросередовища, сімейною групою, дружнім i, нарешті, віртуальним співтовариством, роль якого поступово зростає.

Напрям моральних трансформацій у сучасному суспільстві можна простежити, вивчаючи взаємини поколінь. Поряд з іншими класичними парадигмами постмодерн руйнує значимість вікової ієрархії, створює культ вічної молодості і технологію забуття смерті. Передбачається, що в будь-якому біологічному віці людина повинна бути активною і мобільною. Тому ознакою постмодернізації суспільства могла б вважатися зміна відносин між поколіннями і встановлення якоїсь загальної для всіх системи моральних уявлень, ядром якої були б якісь, умовно кажучи, «молодіжні» цінності.

За свідченням Т. Яковук [10, с. 101], відносини з батьками у сучасній молоді здебільшого мають гармонійний характер: $67 \%$ оцінюють їх як партнерські, 18\% - як ліберальні, і тільки 9\% вважають їх авторитарними. Найбільш високо студенти оцінюють моральний рівень середнього покоління і майже 10\% вважають найбільш моральною молодь. Таким чином, матриця моральних уявлень нашого суспільства, як і раніше, задається старшими поколіннями: «Найбільш популярні зразки життєвого стилю для молоді це завжди дорослі люди, якщо суспільство вміє цінувати цих людей» .

Стійкість морального авторитету старших не означає, однак, безумовного схвалення норми «поважай старших». Більш значущими є міркування про те, що всі люди гідні поваги, до них треба ставитися відповідно до їх реальних заслуг незалежно від віку. У тих випадках, коли традиційна норма «поважай старших» стикається з демократичною ідеєю моральної рівності людей, її значимість знижується, відносини між «батьками» i «дітьми» мають тенденцію розвиватися в напряму «моралі без віку», з єдиними нормами взаємовідносин між будь-якими індивідами. Можна сказати, що соціально-морального конфлікту, тобто принципової різниці між моральними цінностями різних поколінь нашого суспільства, не спостерігається.

Молодь, звичайно, більш схильна до впливу інноваційних культурних процесів, є ознаки того, що в умовах соціальної стабілізації молоді українці переходять «від матеріальних цілей життєдіяльності (матеріальний добробут, порядок і безпеку) до постматеріальних цінностей (можливість самовираження особистості, самоідентифікація, якість життя)» [1, с. 28; 2, с. 29-36]. Але наявність поточних ціннісних орієнтацій ще не означає їх стійкості, а тим більше присутності відповідних структур моральної поведінки.

Період сучасної системної трансформації українського суспільства закономірно характеризується змішаними формами ціннісних орієнтацій. Щодо більшості населення, то «сьогодні ніяк не менше $40 \%$ людей у нашому суспільстві йдуть за традиційними нормами моралі і вважають їх найбільшою цінністю» [4, с. 42-44]. Поліпшення морального стану нашого суспільства багатьма пов'язується зі зверненням до традиційних цінностей українського народу. Однак слід мати на увазі, що установки, які становлять основу традиційної моральності, часто отримують в наш час не традиційну, а модерну, а то і постмодерну інтерпретацію. Можливо, це буде наслідком реставрації традиційних цінностей всередині принципово нових способів моральної регуляції. Мораль сучасної молоді може розглядатися як модель, що дозволяє вивчати природу цих інновацій за збереження спадкоємності в розвитку моральної культури нашого суспільства.

\section{Jimepamypa}

1. Бондаревская Е.В. Личностно ориентированное образование: опыт разработки парадигмы. Ростов н/Д : РГПУ, 1997. С. 28.

2. Бондаревская Е.В. Ценностные основания личностно ориентированного воспитания. Педагогика. 1995. № 4. C. 29-36.

3. Каравкін В.І. Духовні інтенції сучасної молоді (соціологічний аналіз). Вітебськ, 2005. С. 70-72.

4. Коберник I. Моральне виховання: традиції, проблеми, інновації. Рідна школа. 2002. № 5. С. 42-44.

5. Лисовский В.Т. Динамика социальных изменений: опыт сравнительных социологических исследований российской молодежи. СОЦИС. 1999. № 12. C. 27-36.

6. Лисовский В.Т. Духовный мир и ценностные ориентации молодежи : Учебное пособие. Санкт-Петербург : ГУР, 2000. 519 с.

7. Рузецький О.В. Патріотичні цінності студентства Білорусі на рубежі нового тисячоліття. Вітебськ, 2002. C. 62.

8. Титаренко Л.Г. Ціннісний світ сучасного білоруського суспільства: гендерний аспект. Мн., 2004. C. 147.

9. Шумська Л. І. Соціалізація студентської молоді. Мінськ, 2001. С. 176.

10. Яковук T.I. Динаміка ціннісних орієнтацій білоруської молоді періоду системної трансформації суспільства. Брест, 2003. С. 101. 


\section{Анотація}

Варнавська I. В. Сучасні погляди на проблеми моральності як важливого аспекту формування особистості молоді України. - Стаття.

У статті розглядаються проблеми моральності, оскільки визначена проблема $є$ досить важливим складником виховання і формування особистості в сучасному українському суспільстві. В сучасному суспільстві стан моральної освіти можна визначити як незадовільний. Зруйновано систему освіти, яка не тільки задавала ідеологічні орієнтації, а й надавала духовні, моральні та естетичні знання. Унаслідок цього розвиваються вседозволеність і цинізм щодо моральних цінностей народу, вироблених ним протягом багатовікового існування, і щодо патріотизму також. Об'єктивною реальністю стало наростання негативних тенденцій у дитячому і молодіжному середовищі. Сучасний педагог повинен бути здатний до багатоваріантності педагогічних дій, прогнозування важливих виховних результатів, проєктування розвитку особистості, а також він має уявляти, якого громадянина і патріота Батьківщини йому необхідно виховати. Успішне вирішення завдань виховання, істотне поліпшення всього педагогічного процесу, розвиток пізнавальної, трудової активності дітей і молоді безпосередньо пов'язано з удосконаленням підготовки педагогів, їх професійно-педагогічної майстерності, ерудиції та культури (як загальної, так і професійної). У висновках відзначено, що поліпшення морального стану нашого суспільства багатьма пов'язується зі зверненням до традиційних цінностей українського народу. Однак слід мати на увазі, що установки, які становлять основу традиційної моральності, часто отримують в наш час не традиційну, а модерну, а то і постмодерну інтерпретацію. Можливо, це буде наслідком реставрації традиційних цінностей всередині принципово нових способів моральної регуляції. Мораль сучасної молоді може розглядатися як модель, що дозволяє вивчати природу цих інновацій за умови збереження спадкоємності в розвитку моральної культури нашого суспільства.

Ключові слова: мораль, моральне виховання, педагогіка, професійна освіта, економічна освіта.

\section{Summary}

Varnavskaya I. V. Modern views on the problems of morality as an important aspect of the formation of young people in Ukraine. - Article.

Article discusses with the problems of morality, since the identified problem is a fairly important component of the upbringing and formation of personality in modern Ukrainian society. In modern society, the state of moral education can be defined as deeply unsatisfactory. The education system, which not only set ideological orientations, but also provided spiritual, moral and aesthetic knowledge, was destroyed. As a result, permissiveness and cynicism develop in relation to the moral values of the people, developed by them over the centuries of existence, and to patriotism as well. An objective reality was the growing negative trends in children and youth. A modern teacher should be capable of multivariate pedagogical actions, predicting important educational results, projecting personal development, and also imagine what kind of citizen and patriot of the Motherland he needs to raise. Successful solution of educational tasks (in general), significant improvement of the entire pedagogical process, development of cognitive and labor activity of children and youth is directly related to the improvement of teachers training, their professional and pedagogical skills, erudition and culture (both general and professional). The conclusions note that the improvement of the moral state of our society is often associated with an appeal to the traditional values of the Ukrainian people. However, it should be borne in mind that the attitudes that form the basis of traditional morality often receive in our time not a traditional, but a modern, or even postmodern interpretation. Perhaps this will be a consequence of the restoration of traditional values within fundamentally new ways of moral regulation. The morality of modern youth can be considered as a model that allows us to study the nature of these innovations while maintaining continuity in the development of the moral culture of our society.

Key words: morality, moral education, pedagogy, professional education, economic education. 